\title{
Cervical squamous intraepithelial neoplasia grade 1: Recurrence, persistence, and progression in untreated women
}

\author{
Servikal intraepitelyal neoplazi grade 1: Tedavi \\ edilmemiş kadınlarda rekürrens, persistans ve \\ progresyon
}

Hüilya Ayılk Aydın' ${ }^{1}$, Tayfun Toptaş ${ }^{1}$, Tayup Şimşek ${ }^{1}$

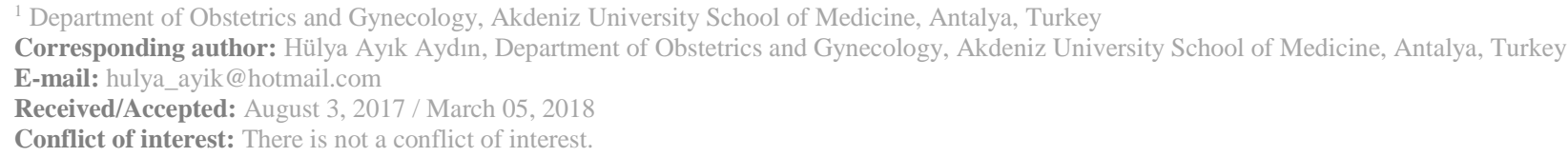

\section{SUMMARY}

Objective: Low grade cervical intraepithelial neoplasia (CIN) is a relatively common disorder. The course of disease including recurrence, persistence, and progression in untreated women is not well-known. The aim of the present study was to determine the natural history of CIN 1 during a follow-up period of 3 years.

Method: This retrospective study involved data extracted from the medical files of 545 patients diagnosed with CIN 1 between 2009 and 2015 in the obstetrics and gynecology department of a tertiary care center. Initial cervical smear results were compared to those on the follow-up visits at $1^{\text {st }}, 2^{\text {nd }}$ and $3^{\text {rd }}$ years.

Results: Comparison of initial smear results with follow-up samples yielded significant improvements on $1^{\text {st }}, 2^{\text {nd }}$, and $3^{\text {rd }}$ years ( $<<0.001$ for all). In patients $\leq 44$ years of age, improvement in smear results on the $2^{\text {nd }}$ year was more noteworthy than those in patients $>44$ years $(\mathrm{p}=0.011)$.

Conclusions: Results of the present study imply that To conclude, our results demonstrated that low-grade CIN lesions are less likely to display a progressive course. Therefore, prolongation of the screening intervals may be logical for the avoidance of unnecessary visits and procedures, improvement of the quality of life and cost-effectivity.

Keywords: Cervical intraepithelial neoplasia, low grade, CIN 1, follow-up, cervical smear.

\section{ÖZET}

Amaç: Düşük dereceli servikal intraepitelyal neoplazi (CIN) oldukça yaygın bir bozukluktur. Tedavi edilmemiş kadınlarda rekürrens, persistans ve progresyonu içeren hastalığın seyri iyi bilinmemektedir. Bu çalışmanın amacı 3 yıllık takip sürecinde CIN1 in doğal gidişatını belirlemektir.

Yöntem: Bu retrospektif çalıșma, 2009 ve 2015 yılları arasında, üçüncü basamak bakım merkezimizdeki jinekolojik onkoloji bölümünde CIN1 tanısı almış 545 hastanın tıbbi verilerini içermektedir. İlk servikal smear sonuçları; 1., 2. ve 3. y1l takiplerdeki sonuçlarla karşılaştırıldı.

Bulgular: İlk smear sonuçları takip örneklerle karşılaştırıldığında 1., 2. ve 3. yıllara kıyasla anlamlı iyileşme göstermiştir $(\mathrm{p}<0.001$ hepsi için). $\leq 44$ yaş hastalarda 2. y1l smear sonuçlarındaki iyileşme, $>44$ yaş hastalardan daha fazla dikkate değer bulundu ( $\mathrm{p}=0.011)$.

Sonuç: Mevcut çalışma sonuçlarına göre, düşük dereceli CIN lezyonları daha az ilerleyici gidişat gösterme eğilimindedirler. Bu yüzden gereksiz vizitleri ve işlemleri önlemek, yaşam kalitesini ve maliyet etkinliği iyileştirmek için tarama aralıklarını uzatmak mantıklı olabilir.

Anahtar sözcükler: Servikal intraepitelyal neoplazi, düşük derece, CIN 1, takip, servikal smear. 


\section{INTRODUCTION}

Cervical intraepithelial neoplasia grade 1 (CIN1) is the most common histopathologic biopsy diagnosis following colposcopy. CIN1 is frequently (and incorrectly) grouped with more severe grades, CIN2 and CIN3, as cervical neoplasia, implying precancer. To some extent, this is due to the diagnostic challenge of distinguishing CIN1 from CIN2 and negative histology reproducibly ${ }^{1,2}$.

The clinical implications of CIN1 are not well revealed as there are limited prospective studies to explore the subsequent risk of cervical precancer. Ostor et al. suggested that $10 \%$ of patients with CIN1 develop CIN3 in the next 10 years ${ }^{3}$. In the atypical squamous cells of undetermined significance (ASCUS) and low-grade squamous intraepithelial lesion (LSIL), the two-year risk of CIN3 was $9 \%{ }^{4}$. Elit et al. performed a randomized trial for the management of CIN 1 and stated that $4.4 \%$ of CIN1 were diagnosed with CIN2/3 in 18 months ${ }^{5}$. Bansal et al. analyzed 1,001 CIN1 and stated that, at the 6-month follow-up, 7\% were diagnosed with $\mathrm{CIN} 2 / 3^{6}$. The extensively variable results among studies may be due to several aspects, including diagnostic faults, variances in diagnostic thresholds for individual CIN category, population differences, and the time of follow-up.

The optimal management of women with lowgrade biopsy-proven CIN is not clear. In the present study, we aimed to ascertain the natural history of CIN 1 during a follow-up period of 3 years.

\section{MATERIAL AND METHODS}

\section{Study design}

The study has been conducted by the principles of the Helsinki Declaration and approved by the local Institutional Review Board.

Data of 1794 patients, admitted to the Department of Obstetrics and Gynecology of Akdeniz University Medical Faculty and underwent colposcopy, between 2009 and 2015 met the eligibility criteria for the study. Of these 1794 patients, 545 patients whose cervical biopsy results were CIN 1 constituted the study group.

Patients were classified according to the histopathological results of smears as follows: 1 . Normal, 2. Atypical squamous cells of undetermined significance (ASCUS), 3. Lowgrade squamous intraepithelial lesion (LSIL). The colposcopic examination was followed by achievement of cervical biopsies which were reported as CIN1.

Patients were excluded for any of the following: index PAP smear showed CIN2, CIN3, or cancer (CIN2/3/cancer), atypical glandular cells of unknown significance, or glandular dysplasia requiring immediate investigation; extension of the CIN1 lesion to the vagina, a separate vaginal lesion showing dysplasia, or a colposcopically-visible condyloma outside of the transformation zone; known allergy to local analgesics; unsatisfactory colposcopy (defined by inability to see the extent of the lesion in the endocervical canal or absence of a lesion on the ectocervix, but endocervical curettage shows CIN1); currently pregnant; prior therapy for dysplasia including medical, surgical (laser, LEEP), or cryotherapy; prior gynecologic cancer, pelvic radiation; other malignancies except nonmelanoma skin cancer; immunosuppressed because of diseases, or on immunosuppressive medications (such as prednisone, Imuran, or chemotherapy); already in a surveillance program for biopsy-proven CIN1; unable to attend followup visits because of geographic inaccessibility.

\section{Outcome parameters}

Initially, cervical smear cytology and biopsies were achieved. At the follow-up visits, scheduled on $1^{\text {st }}$, $2^{\text {nd }}$, and $3^{\text {rd }}$ years, patients underwent cervical cytology and a colposcopic examination.

\section{Statistical analysis}

Data were analyzed using the IBM Statistical Package for Social Sciences v22 (SPSS Inc., Chicago, IL, USA). A normal distribution of the quantitative data was checked using KolmogorovSmirnov test. Mc Nemar test was used to compare dependent groups. The distribution of categorical variables in both groups was compared using chisquare and Fisher tests. Continuous data were presented as mean \pm standard deviation or median [minimum-maximum], as appropriate. All differences associated with a chance probability of 0.05 or less were considered statistically significant.

\section{RESULTS}

Results of cervical smears and biopsies obtained on the initial examination and 3 consecutive follow-up visits are shown in Tables $\mathbf{1}$ and $\mathbf{2}$, respectively. 
Table 1. Histopathological results of cervical smears in our series.

\begin{tabular}{|c|c|c|}
\hline Interval & Smear & $\mathbf{n}(\%)$ \\
\hline \multirow{3}{*}{ Initial } & Normal & $79(14.5)$ \\
\cline { 2 - 3 } & ASCUS & $150(27.5)$ \\
\cline { 2 - 3 } & LSIL & $316(58)$ \\
\hline \multirow{4}{*}{$1^{\text {st }}$ year } & Normal & $335(61.5)$ \\
\cline { 2 - 3 } & ASCUS & $126(23.1)$ \\
\cline { 2 - 3 } & LSIL & $84(15.4)$ \\
\hline $2^{\text {nd }}$ year & Normal & $344(63.1)$ \\
\cline { 2 - 3 } & ASCUS & $37(12)$ \\
\cline { 2 - 3 } & LSIL & 12 \\
\cline { 2 - 3 } & N/A & $152(27.9)$ \\
\hline \multirow{7}{*}{ rd $^{\text {rd }}$ year } & Normal & $216(39.6)$ \\
\cline { 2 - 3 } & ASCUS & $2(0.4)$ \\
\cline { 2 - 3 } & LSIL & $4(0.7)$ \\
\cline { 2 - 3 } & N/A & $323(59.3)$ \\
\hline
\end{tabular}

(Abbreviations: ASCUS: atypical squamous cells of undetermined significance; LSIL: low-grade squamous intraepithelial lesions, N/A: not available)

Table 2. An overview of cervical biopsy results.

\begin{tabular}{|c|c|c|}
\hline Interval & Smear & $\mathbf{n}(\%)$ \\
\hline \multirow{3}{*}{ Initial } & CIN1 & $544(99.8)$ \\
\cline { 2 - 3 } & CIN2 & $150(27.5)$ \\
\hline \multirow{4}{*}{$1^{\text {st }}$ year } & Normal & $4(0.7)$ \\
\cline { 2 - 3 } & CIN1 & $91(16.7)$ \\
\cline { 2 - 3 } & CIN2 & $3(0.6)$ \\
\cline { 2 - 3 } & N/A & $447(82.0)$ \\
\hline \multirow{7}{*}{$2^{\text {nd }}$ year } & Normal & $6(1.1)$ \\
\cline { 2 - 3 } & CIN1 & $13(2.4)$ \\
\cline { 2 - 3 } & N/A & $526(96.5)$ \\
\hline $3^{\text {rd }}$ year & Normal & $2(0.4)$ \\
\cline { 2 - 3 } & CIN1 & $3(0.6)$ \\
\cline { 2 - 3 } & N/A & $540(99.1)$ \\
\hline
\end{tabular}

(Abbreviations: CIN: cervical intraepithelial neoplasia; N/A: not available)

Comparison of initial smear results with follow-up samples yielded significant improvements in $1^{\text {st }}$, $2^{\text {nd }}$, and $3^{\text {rd }}$ years $(\mathrm{p}<0.001$ for all $)$ (Table 3). Thirty-one of 36 patients presenting with worse smear results on the $1^{\text {st }}$ year were evaluated again on $2^{\text {nd }}$ year. These smears indicated more favorable results in 28 of 31 patients $(90.3 \%$ ), while 3 cases displayed no remarkable changes and this difference was found to be statistically significant $(\mathrm{p}<0.001)$. 
Table 3. Comparison of the changes in smear results during 3 consecutive follow-up visits (Mc Nemar test was used for statistical analysis).

\begin{tabular}{|c|c|c|c|c|c|c|c|c|}
\hline \multirow[t]{3}{*}{ Interval } & \multirow[t]{3}{*}{ Result } & \multicolumn{3}{|c|}{ Initial } & \multicolumn{3}{|c|}{ Change } & \multirow[t]{3}{*}{ p-value } \\
\hline & & \multirow{2}{*}{ Normal } & \multirow[t]{2}{*}{ ASCUS } & \multirow[t]{2}{*}{ LSIL } & $\mathbf{U}$ & I & D & \\
\hline & & & & & n (\%) & n (\%) & n (\%) & \\
\hline \multirow{3}{*}{$1^{\text {st }}$ year } & Normal & 55 & 106 & 174 & \multirow{3}{*}{$\begin{array}{c}150 \\
(27.5)\end{array}$} & \multirow{3}{*}{$\begin{array}{c}359 \\
(65.9)\end{array}$} & \multirow{3}{*}{$\begin{array}{c}36 \\
(6.6)\end{array}$} & \multirow[t]{3}{*}{$<0.001^{*}$} \\
\hline & ASCUS & 15 & 32 & 79 & & & & \\
\hline & LSIL & 9 & 12 & 63 & & & & \\
\hline \multirow[t]{4}{*}{$2^{\text {nd }}$ year } & Normal & 50 & 107 & 187 & \multirow{4}{*}{$\begin{array}{c}69 \\
(17.6)\end{array}$} & \multirow{4}{*}{$\begin{array}{c}320 \\
(81.4)\end{array}$} & \multirow[t]{4}{*}{$4(1)$} & \multirow[t]{4}{*}{$<0.001 *$} \\
\hline & ASCUS & 2 & 9 & 26 & & & & \\
\hline & LSIL & 1 & 1 & 10 & & & & \\
\hline & N/A & 26 & 33 & 93 & & & & \\
\hline \multirow[t]{4}{*}{$3^{\text {rd }}$ year } & Normal & 31 & 62 & 123 & \multirow{4}{*}{$\begin{array}{c}34 \\
(15.3)\end{array}$} & \multirow{4}{*}{$\begin{array}{c}187 \\
(84.2)\end{array}$} & \multirow[t]{4}{*}{$1(0.5)$} & \multirow[t]{4}{*}{$<0.001^{*}$} \\
\hline & ASCUS & 0 & 0 & 2 & & & & \\
\hline & LSIL & 0 & 1 & 3 & & & & \\
\hline & N/A & 48 & 87 & 188 & & & & \\
\hline
\end{tabular}

(Abbreviations: ASCUS: atypical squamous cells of undetermined significance; LSIL: low-grade squamous intraepithelial lesions, N/A: not available; U: unchanged; I: increased; D: decreased)

Alteration of initial smear results on the $1^{\text {st }}$ year was insignificant in patients $\leq 44$ years and $>44$ years of age $(p=0.100)$. In patients $\leq 44$ years of age, improvement of smear results on the $2^{\text {nd }}$ year was more noteworthy than that in patients $>44$ years $(\mathrm{p}=0.011)$. Comparison of initial smear results with those on $3^{\text {rd }}$ and $4^{\text {th }}$ years in patients $\leq$ 44 years and $>44$ years of age indicated that there were no significant differences $(p=0.163$ and $\mathrm{p}=0.937$, respectively) (Table 4).

Table 4. Comparison of improvement with respect to initial cervical smear results in patients $\leq 44$ years and $>44$ years of age (statistical analysis was performed with $X^{2}$ : chi square test)

\begin{tabular}{|l|l|l|l|}
\hline \multirow{2}{*}{ Time of cervical smear } & Age $\leq \mathbf{4 4}$ years & Age $>$ 44 years & p-value \\
\cline { 2 - 4 } & $\mathbf{n}(\boldsymbol{\%})$ & $\mathbf{n}(\boldsymbol{\%})$ & \\
\hline $1^{\text {st }}$ year & $183(69.3)$ & $176(62.6)$ & 0.100 \\
\hline $2^{\text {nd }}$ year & $149(87.1)$ & $171(77.0)$ & $0.011^{*}$ \\
\hline $3^{\text {rd }}$ year & $88(88.0)$ & $99(81.1)$ & 0.163 \\
\hline $4^{\text {th }}$ year & $214(81.1)$ & $226(80.4)$ & 0.937 \\
\hline
\end{tabular}

\section{DISCUSSION}

Recently, there has been changes in diagnostic and therapeutic methods used for identification of cervical cancer precursors. Early detection of these precursors via screening programs is critical for appropriate treatment ${ }^{7}$. There is still controversy on the natural history of low-grade CIN lesions. Inconsistent results on follow-up of low-grade CINs is attributed to the cytologic criteria, duration of the abnormality of smear before enrollment, the utilization of biopsies for ascertainment, and the lack of consistent statistical treatment of the follow-up data ${ }^{7}$.

The poor reproducibility of the histologic diagnosis of CIN1, and the uncertain biologic potential of lesions classified as CIN1 makes management of these women problematic. It must be remembered that utilization of cytologic or histologic methods alone may not be sufficient to figure out whether a CIN1 is frankly a persistent lesion or indicates a new lesion ${ }^{8}$.

In the present study, we aimed to ascertain the natural history of CIN1 during 4 years of a followup period. Our study showed that careful examination of alterations in repeated cervical smears provides useful data for follow-up of patients diagnosed initially for CIN 1 . Understanding the natural course of low-grade CIN may aid in the establishment of recommendations for a more effective follow-up regimen.

For women with biopsy-proven CIN1, the advantage of a watchful waiting strategy using regular colposcopic follow-up is that only those with persistent CIN1 or high-grade disease are 
treated. The disadvantage is that the extended follow-up increases patient inconvenience, concern, and noncompliance ${ }^{9}$.

Understanding the natural course of low-grade CIN may aid in the establishment of recommendations for more effective and practical follow-up of these lesions. We hope that our results will provide novel insights on the natural course of CIN lesions. Effective management of CIN necessitates optimization of screening and triage of patients, and this process is dependent on several factors including the degree of dysplasia, environmental factors, age, tobacco use, and the presence of highrisk human papilloma virus (HPV) types ${ }^{6-8}$.

The remarkable decrease in the prevalence and mortality rate due to cervical cancer may be associated with the establishment of more effective screening programs. A successful screening program is closely related with the observation of the progression of CIN to an invasive cervical cancer. Screening programs permit identification of the precursor lesions which may be more effectively treated. Cervical cytologic screening may possess disadvantages such as unnecessary visits, and procedures which may lead to patient anxiety and increased cost without noteworthy patient benefit. Hence, determination of the optimal screening interval is crucial for scheduling patient follow-up. Understanding the natural history of these abnormalities can help elucidate the optimal management of abnormal screening tests. We hypothesize that current follow-up programs can be simplified owing to the high rate of spontaneous regression of CIN1 lesions ${ }^{6}$.

Interestingly, we observed that annual follow-up visits were sufficient for patients with low-grade CIN. This frequency allowed patients to be more obedient and adaptable to their clinical appointments in spite of the prolonged time course. Cervical smear constituted a safe, practical and noninvasive method for monitorization of patients with CIN1.

From a clinical perspective, women with CIN1 had a $10 \%$ two-year risk of CIN3 compared to $7 \%$ for negative histology and $6 \%$ for no biopsy, statistically significant but small absolute risk differences ${ }^{10}$. Given the general similarities in risk, these outcomes of screening might be managed similarly. That is, given that there are a limited number of management options (routine screening, increased surveillance, or follow-up colposcopy) and the general similarities in risk, it might difficult to justify differential management by histologic status in this population, depending on the accepted thresholds of risk for each management option.
Follow-up protocols for women with CIN1 are variable. Some protocols use cytology alone, while others utilize a combination of cytology and periodic colposcopy. Follow-up intervals range between 3 to 12 months, and the length of time during which women are followed with CIN1 before treatment is recommended varies from months to years. Current recommendations on the follow-up of patients with CIN1 necessitate repetitive cytology at 6 and 12 months or HPV testing at 12 months ${ }^{8}$. Following two negative cytologic samples or a negative HPV test, the recommendation is to return to annual screening ${ }^{8}$. Our results remind that annual cervical cytology studies may be sufficient for the majority of patients with CIN1.

In the present study, in patients $\leq 44$ years of age, improvement of smear results on the $2^{\text {nd }}$ year was more noteworthy than that in patients $>44$ years $(\mathrm{p}=0.011)$. Especially low-grade cervical lesions may spontaneously regress to lower stages or to the normal condition ${ }^{11}$. Melnikow et al. reported that up to $58 \%$ of patients with abnormal Pap smear regress over 24 months ${ }^{12}$. Matsumoto et al. also reported spontaneous regression of low-grade lesions in more than $68 \%$ of patients ${ }^{13}$. Moscicki et al. investigated 187 women with LSIL and found that $61 \%$ of them regressed over 12 months of follow-up ${ }^{14}$. The heightened rate of LSIL regression noted in young women indicates a high rate of resolution in HPV infections ${ }^{15}$. Older women with LSIL on cytology might represent a population with HPV infections that are not transient, but rather show true persistence, which is a risk for HSIL.

The main limitation of our study was the retrospective nature. The second limitation is the experience restricted to the outcomes of a single institution. Third, some details of history and factors that may influence the outcome may not be completely documented. Fourth, the lack of a matched control group due to the observational character of this report. Due to these restrictions, associations should be interpreted with caution.

To conclude, our results demonstrated that lowgrade CIN lesions are less likely to display a progressive course. Therefore, prolongation of the screening intervals may be logical for the avoidance of unnecessary visits and procedures, improvement of the quality of life and costeffectivity. 


\section{REFERENCES}

1. Carreon JD, Sherman ME, Guillen D, Solomon D, Herrero R, Jeronimo J, Wacholder S, Rodriguez AC, Morales J, Hutchinson M, et al. CIN2 is a much less reproducible and less valid diagnosis than CIN3: results from a histological review of population-based cervical samples. Int $\mathbf{J}$ Gynecol Pathol 2007; 26: 441-6.

2. Castle PE, Stoler MH, Solomon D, Schiffman M. The Relationship of Community Biopsy-Diagnosed Cervical Intraepithelial Neoplasia Grade 2 to the Quality Control Pathology-Reviewed Diagnoses: An ALTS Report. Am J Clin Pathol 2007; 127: 805-15.

3. Ostor AG. Natural history of cervical intraepithelial neoplasia: a critical review. Int J Gynecol Pathol 1993; 12: 186-92.

4. Cox JT, Schiffman M, Solomon D. Prospective follow-up suggests similar risk of subsequent cervical intraepithelial neoplasia grade 2 or 3 among women with cervical intraepithelial neoplasia grade 1 or negative colposcopy and directed biopsy. Am J Obstet Gynecol 2003; 188: 1406-12.

5. Elit L, Levine MN, Julian JA, Sellors JW, Lytwyn A, Chong S, Mahony JB, Gu C, Finch T, Zeferino LC. Expectant management versus immediate treatment for low-grade cervical intraepithelial neoplasia: a randomized trial in Canada and Brazil. Cancer 2011; 117: 1438-45.

6. Bansal N, Wright JD, Cohen CJ, Herzog TJ. Natural history of established low grade cervical intraepithelial (CIN 1) lesions. Anticancer Res 2008; 28(3B): 1763-6.

7. Dijkstra MG, Snijders PJ, Arbyn M, Rijkaart DC, Berkhof J, Meijer CJ. Cervical cancer screening: on the way to a shift from cytology to full molecular screening. Ann Oncol 2014 May; 25: 92735.

8. Wright TC Jr, Cox JT, Massad LS, Twiggs LB, Wilkinson EJ: 2001 Consensus
Guidelines for the management of women with cervical cytological abnormalities. ASCCP-Sponsored Consensus Conference. JAMA 2002; 287: 2120-9.

9. Cuvelier CA, Bogers JP, Bourgain C, Delvenne P, Drijkoningen M, Garbar C, Kevers M, Remmelinck M, Thienpont L, Verhest A, Weynand B, Willocx F. Belgian consensus guidelines for followup of women with cervical cytological abnormalities. Acta Clin Belg 2009; 64: 136-43.

10. Castle PE, Sideri M, Jeronimo J, Solomon D, Schiffman M. Risk assessment to guide the prevention of cervical cancer. J Low Genit Tract Dis 2008; 12: 1-7.

11. Trimble CL, Piantadosi $S$, Gravitt $P$, Ronnett B, Pizer E, Elko A, et al. Spontaneous regression of high-grade cervical dysplasia: Effects of human papillomavirus type and HLA phenotype. Clin Cancer Res 2005; 11: 4717-23.

12. Melnikow J, Nuovo J, Willan AR, Chan BK, Howell LP. Natural history of cervical squamous intraepithelial lesions: A metaanalysis. Obstet Gynecol 1998; 92: $727-$ 35.

13. Matsumoto K, Oki A, Furuta R, Maeda $H$, Yasugi T, Takatsuka N, et al. Tobacco smoking and regression of low-grade cervical abnormalities. Cancer Sci 2010; 101: 2065-73.

14. Moscicki AB, Shiboski S, Hills NK, Powell KJ, Jay N, Hanson EN, et al. Regression of low-grade squamous intraepithelial lesions in young women. Lancet. 2004; 364: 1678-83.

15. Moscicki AB1, Shiboski S, Hills NK, Powell KJ, Jay N, Hanson EN, Miller S, Canjura-Clayton KL, Farhat S, Broering JM, Darragh TM. Regression of low-grade squamous intra-epithelial lesions in young women. Lancet 2004, 6-12; 364 (9446): 1678-83. 